\title{
THE DIAGNOSTIC VALUE OF SCUBE1 IN PATIENTS PRESENTING TO THE EMERGENCY DEPARTMENT DUE TO ANGINA PECTORIS
}

\author{
Angina Pektoris Nedeniyle Acile Başvuran Hastaların Tanısında Scube1'in Dĕgeri
}

\author{
Aynur ŞAHİN ${ }^{1}$, Süha TÜRKMEN ${ }^{2}$, Ahmet MENTEŞE ${ }^{3}$, Süleyman Caner KARAHAN ${ }^{4}$, \\ Mücahit GÜNAYDIN ${ }^{5}$, Süleyman TÜREDİ1 ${ }^{1}$, Abdülkadir GÜNDÜZ1 \\ ${ }^{I}$ Karadeniz Teknik Üniversitesi, Tip Fakültesi, Acil Tip Anabilim Dall, TRABZON, TÜRKIYE. \\ ${ }^{2}$ Acıbadem Üniversitesi, Tip Fakültesi, Acil Tip Anabilim Dal, ISTANBUL, TÜRKIYE. \\ ${ }^{3}$ Karadeniz Teknik Üniversitesi, Sağllk Bilimleri MYO, Tibbı Laboratuvar Teknikleri A.D., TRABZON, TÜRKIYE. \\ ${ }^{4}$ Karadeniz Teknik Üniversitesi, Tip Fakültesi, Tibbi Biyokimya Anabilim Dall, TRABZON, TÜRKIYE. \\ ${ }^{5}$ Giresun Üniversitesi, Tip Fakültesi, Acil Tip Anabilim Dall, GIRESUN, TÜRKIYE.
}

\begin{abstract}
Objective: The purpose of this study was to investigate the value of signal peptide-CUB-EGF domain-containing protein 1 (SCUBE1) in the diagnosis of angina pectoris in patients presenting to the emergency department.

Material and Methods: This prospective research was planned as a cross-sectional, single-center clinical study. Patients presenting to the emergency department with angina pectoris symptoms over a period of five months from receipt of ethical committee approval were included. Patients presenting with ischemic chest pain were divided on the basis of etiology into stable angina pectoris (SAP), unstable angina pectoris (UAP), non-ST elevation myocardial infarction (NSTEMI), and ST segment elevation myocardial infarction (STEMI) groups. Clinical, laboratory and demographic characteristics were recorded. SCUBE1 levels from each group were compared with a healthy control group.

Results: A total of 118 individuals were enrolled in the study, 78 patients meeting the inclusion criteria and 40 healthy controls. Patients' mean age was $54.36 \pm 14.03$ years, and $88.5 \%(\mathrm{n}=69)$ were male. Hypertension $(59 \%)$ and smoking $(62 \%)$ predominated over other risk factors. NSTEMI was the most common factor (46.1\%) in patients enrolled due to ischemic chest pain. No statistically significant difference was determined between patients' serum SCUBE1 levels at time of presentation and at $6 \mathrm{~h}$ and $12 \mathrm{~h}$ and the control group ( $>0.05$ ).
\end{abstract}

Conclusion: On the basis of our study findings, SCUBE1 is of no value in the diagnosis of ischemic chest pain etiologies.

Keywords: Angina pectoris, SCUBE1, acute coronary syndrome

\section{ÖZ}

Amaç: $\mathrm{Bu}$ çalışmanın amacı gögüs ağrısı nedeniyle acil servise başvuran hastalarda Signal peptide-CUB-EGF Domain-containing Protein 1 (SCUBE 1)'in angina pektoris tanısındaki değerini araştırmaktır.

Gereç ve Yöntemler: $\mathrm{Bu}$ çalışma prospektif, kesitsel, tek merkezli bir klinik çalışma olarak planlandı. Etik kurul onayının alınmasından itibaren toplam 5 ay süreyle acil servise iskemik göğüs ağrısı şikayetiyle başvuran hastalar dahil edildi. İskemik göğüs ağrısı ile başvuran hastalar etyolojilerine göre stabil angina pektoris (SAP), unstabil angina pektoris (UAP), ST elevasyonu olmayan myokard infarktüsü (NSTEMI), ST elevasyonlu myokard infarktüsü (STEMI) olmak üzere gruplara ayrıldı. Klinik, laboratuar ve demografik özellikleri kayıt altına alındı. Her bir gruptan ölçülen serum SCUBE 1 düzeyleri istatistiksel olarak analiz edilerek sağlıklı kontrol grubuyla karşılaştırılarak analiz edildi.

Bulgular: Çalışmanın dahil etme kriterlerine uygunluk gösteren 78 hasta ile 40 sağliklı kontrol olmak üzere toplam 118 kişi çalışmaya alındı. Hastaların yaş ortalaması $54.36 \pm 14.03$ olup \%88.5'i (n=69) tanesi erkekti. Hastaların risk faktörleri incelendiğinde HT(\%59) ve sigara (\%62) diğer risk faktörlerine göre daha ağırlıktaydı. İskemik göğüs ağrısı şikayetiyle çalışmaya dahil ettiğimiz hastalarda en sik etken NSTEMI olarak tespit edildi (\%46.1). Hastaların başvuru anında, 6.saat ve 12. saat serum SCUBE-1 değerleri kontrol grubu ile karşıllaştırıldığında istatiksel olarak anlamlı fark bulunmadı ( $\mathrm{p}>0.05)$.

Sonuç: Çalışmamızın bulgularına göre SCUBE 1, iskemik göğüs ağrısı etiyolojilerinin tanısında değeri bulunmamaktadır.

Anahtar Kelimeler: Angina pektoris, SCUBE1, akut koroner sendrom 


\section{INTRODUCTION}

Ischemic chest pain, also known as 'angina pectoris' occurs in the myocardium if the coronary arteries fail to supply myocardial oxygen requirements. It emerges due to the stimulation of sympathetic nerve receptors in this region. Ischemic chest pain manifests with pressure, contraction and a burning-type pain in clinical practice, and is a common cause of emergency department presentations $(1,2)$. Early diagnosis of underlying myocardial ischemia and appropriate treatment being initiated as quickly as possible play an important role in reducing mortality and morbidity, particularly in the presence of acute coronary syndrome (ACS); unstable angina pectoris (UAP), non-ST elevation myocardial infarction (NSTEMI) and ST elevation myocardial infarction (STEMI). ACS leads to approximately 7 million deaths and to morbidity compromising quality of life of some 129 million individuals a year (3). Algorithms based on up-to-date guidelines are currently used in the standardization of diagnosis and treatment of ACS patients. Problems such as missed or late diagnosis are experienced in the emergency department, particularly in presentations with non-specific clinical findings, in UAP and NSTEMI patients with non-specific electrocardiogram findings but without ST elevation.

Signal peptide-CUB (complement C1r/C1s, Uegf, and Bmp1)-EGF (epidermal growth factor)-like domaincontaining protein 1 (SCUBE1) is a cell surface protein released from early embryogenesis. SCUBE1 is expressed in the endothelium and platelets and is a potential marker of platelet activation (4). This molecule is stored in alpha granules in inactivated platelets and is released into the thrombus from the cell surface following thrombin-activated platelet activation (5). In addition, SCUBE1 accumulation has been shown immunohistochemically in the subendothelial matrix of atherosclerotic lesions in humans (6). Various experimental and clinical studies have determined that plasma SCUBE1 rises in ischemic events developing secondary to platelet activation and aggregation. SCUBE1 can be measured in plasma using the enzyme-linked immunosorbent assay (ELISA) method, but has still not yet entered into routine clinical use (7).

The purpose of this study was to investigate the diagnostic value of serum SCUBE1 levels, shown to elicit significant results in several ischemic events, including cardiovascular system pathologies, in angina pectoris.

\section{MATERIALS AND METHODS}

Approval for this prospective, cross-sectional, single center was granted by the Instutional Clinical Research Ethical Committee (No. 2011/61). Following that approval, all patients aged 18 or over presenting to the emergency department due to angina pectoris, diagnosed with clinical, ECG and laboratory examinations and agreeing to take part over a fivemonth period were included in the study. Pregnant patients and subjects with a history of pulmonary embolism, acute kidney failure, chronic kidney failure, liver failure, peripheral artery disease or acute trauma or whose blood levels could not be monitored were excluded.

\section{Establishment of the Study Groups}

Detailed history, physical examination, laboratory methods and the European Society of Cardiology ACS management guideline were used for the diagnosis ACS (8). Blood specimens were collected from patients presenting to the emergency due to angina pectoris on the basis of these criteria at time of presentation, and at the $6^{\text {th }}$ and $12^{\text {th }}$ hours of chest pain. Patients' demographic, clinical and laboratory data were recorded on study forms. STEMI, NSTEMI, UAP, and SAP patient subgroups were established depending on duration of ischemic chest pain at ECGs, presence of ST segment elevation at ECGs, and cardiac enzyme results. Control group patients consisting of 
healthy individuals consenting to take part in the study were enrolled with the collection of blood specimens only.

\section{Biochemical Analysis}

Blood specimens collected from the patients included in the study group at time of presentation and the members of the healthy control group for measurement of SCUBE1 levels were placed into heparin-containing tubes. These were then centrifuged for $10 \mathrm{~min}$ at 3000 rpm for serum and plasma separation. Specimens were pipetted into Eppendorf tubes and stored at $-80{ }^{\circ} \mathrm{C}$. A commercial ELISA kit (Catalog No. CSBE15005 h, Cusabio Biotech Co., P.R. China) was used in accordance with the manufacturer's instructions for the measurement of SCUBE1 levels. Specimen absorbances were determined on a VERSA max tunable microplate reader (designed by Molecular Devices, Sunnyvale, CA) at a wavelength of $450 \mathrm{~nm}$. The results were expressed as $n g / m L$. The minimum detectable SCUBE1 dose is $0.16 \mathrm{ng} / \mathrm{mL}$.

Data Analysis

Patient data at the end of the study were independently assigned into control, UAP and NSTEMI groups. Data were loaded onto Statistical Package for the Social Sciences (SPSS) 14.0 software. Clinical and demographic characteristics such as age, sex, risk factors and accompanying symptoms were expressed as descriptive statistics. Compatibility with normal distribution of biochemical measurements was assessed using the Kolmogorov-Smirnov test. For quantitative data, the independent samples $\mathrm{t}$ test was used for intergroup comparisons of normally distributed data. Pearson correlation analysis was employed to determine the effect on the other variable when one variable value changed. $\mathrm{p}<0.05$ was regarded as statistically significant.

\section{RESULTS}

One-hundred-eighteen patients presented to the emergency department due to angina pectoris over the five-month study period. Seventy-eight patients meeting the inclusion criteria and with no exclusion criteria were finally enrolled. Forty patients meeting the exclusion criteria were excluded from the study. Additionally, 40 healthy subjects were included in the study as control group. Examination of the etiologies of patients' chest pains identified $50 \%$ as NSTEMI $(\mathrm{n}=39), 17 \%$ as STEMI $(\mathrm{n}=13), 18 \%$ as UAP $(\mathrm{n}=14)$ and $15 \%$ as $\operatorname{SAP}(n=12)$.

Patients' risk factors and demographic characteristics are shown in Table 1. The predominant risk factors were identified as HT (59\%) and smoking (62\%).

According to ECG records at time of presentation, ST segment elevation was present in 13 patients. ST segment depression and $\mathrm{T}$ wave inversion were present in 22 patients, while nonspecific findings were present in the ECG records of 39 patients. Laboratory parameters in the patient group were mean platelet count (mean \pm SD) $231794 \pm 64880$, mean creatinine level $0.97 \pm 0.23$ and mean hemoglobin value $14.5 \pm$ 1.47 .

SCUBE1 values measured at time of presentation for each independent angina pectoris cause and SCUBE1 values measured in the control group are shown in Table 2. No statistically significant variation was observed between SCUBE1 values measured at time of presentation in all the patient groups and the control group $(p>0.05)$. Comparison of the primary and secondary headache groups at time of presentation in terms of serum IMA levels revealed no statistically significant difference between the two groups $(\mathrm{p}=0.71)$. Examination of time-dependent changes in SCUBE1 levels revealed that these increased after time of presentation and then tended to decrease after $6 \mathrm{~h}$ (Figure 1). 
Table 1: Clinical and demographic characteristics of the study group

Clinical-demographic characteristics

\begin{tabular}{|c|c|c|}
\hline \multirow{2}{*}{$\begin{array}{l}\text { Age }(\text { mean } \pm \text { SD }) \\
\text { Sex }\end{array}$} & \multicolumn{2}{|c|}{$54.36 \pm 14.03$} \\
\hline & $\mathbf{n}$ & $\%$ \\
\hline M (Male) & 69 & 88.5 \\
\hline F (Female) & 9 & 11.5 \\
\hline \multicolumn{3}{|l|}{ Chest pain characteristics } \\
\hline Chest pain exceeding $20 \mathrm{~min}$ in duration & 49 & 62.8 \\
\hline New onset and activity restricting chest pain & 26 & 33.3 \\
\hline Chest pain triggered by effort & 17 & 21.8 \\
\hline Intensifying angina-type pain & 27 & 34.6 \\
\hline Pleuritic chest pain & 6 & 7.7 \\
\hline Localizable pain & 2 & 2.6 \\
\hline Mechanical-type pain & 6 & 7.7 \\
\hline \multicolumn{3}{|l|}{ Risk factors } \\
\hline Previous history of CAD & 25 & 32.1 \\
\hline Hypertension & 46 & 59.0 \\
\hline Smoking & 52 & 66.7 \\
\hline Previous history of MI & 26 & 33.3 \\
\hline Diabetes & 9 & 11.5 \\
\hline Obesity & 12 & 15.4 \\
\hline Hyperlipidemia & 13 & 16.7 \\
\hline Family history & 9 & 11.5 \\
\hline Sedentary lifestyle & 15 & 19.2 \\
\hline Renal disease & 2 & 2.6 \\
\hline
\end{tabular}

Table 2: Plasma SCUBE1 levels in the study and control groups

\begin{tabular}{|c|c|c|c|c|c|c|}
\hline & \multicolumn{6}{|c|}{ Plasma SCUBE-1 levels (ng/ml) } \\
\hline & $\begin{array}{l}\text { Time of admission } \\
\quad(\text { mean } \pm \text { SD })\end{array}$ & $p$ & $\begin{array}{c}6^{\text {th }} \text { hour } \\
(\text { mean } \pm \mathrm{SD})\end{array}$ & $p$ & $\begin{array}{c}12^{\text {th }} \text { hour } \\
(\text { mean } \pm \mathrm{SD})\end{array}$ & $p$ \\
\hline STEMI & $30.18 \pm 15.6$ & 0.63 & $37.58 \pm 23.24$ & 0.74 & $25.74 \pm 22.87$ & 0.23 \\
\hline NSTEMI & $28.72 \pm 13.2$ & 0.58 & $32.64 \pm 21.65$ & 0.56 & $17.86 \pm 16.20$ & 0.12 \\
\hline UAP & $23.64 \pm 11.7$ & 0.21 & $29.79 \pm 23.40$ & 0.48 & $29.53 \pm 20.4$ & 0.51 \\
\hline SAP & $25.92 \pm 18.3$ & 0.32 & $32.54 \pm 17.67$ & 0.70 & $21.54 \pm 18.9$ & 0.31 \\
\hline
\end{tabular}

Control plasma SCUBE1 level (mean \pm SD): $35.02 \pm 22.31$

Independent Samples t Test, $\mathrm{p}$ values $<0.05$ are statistically significant. 


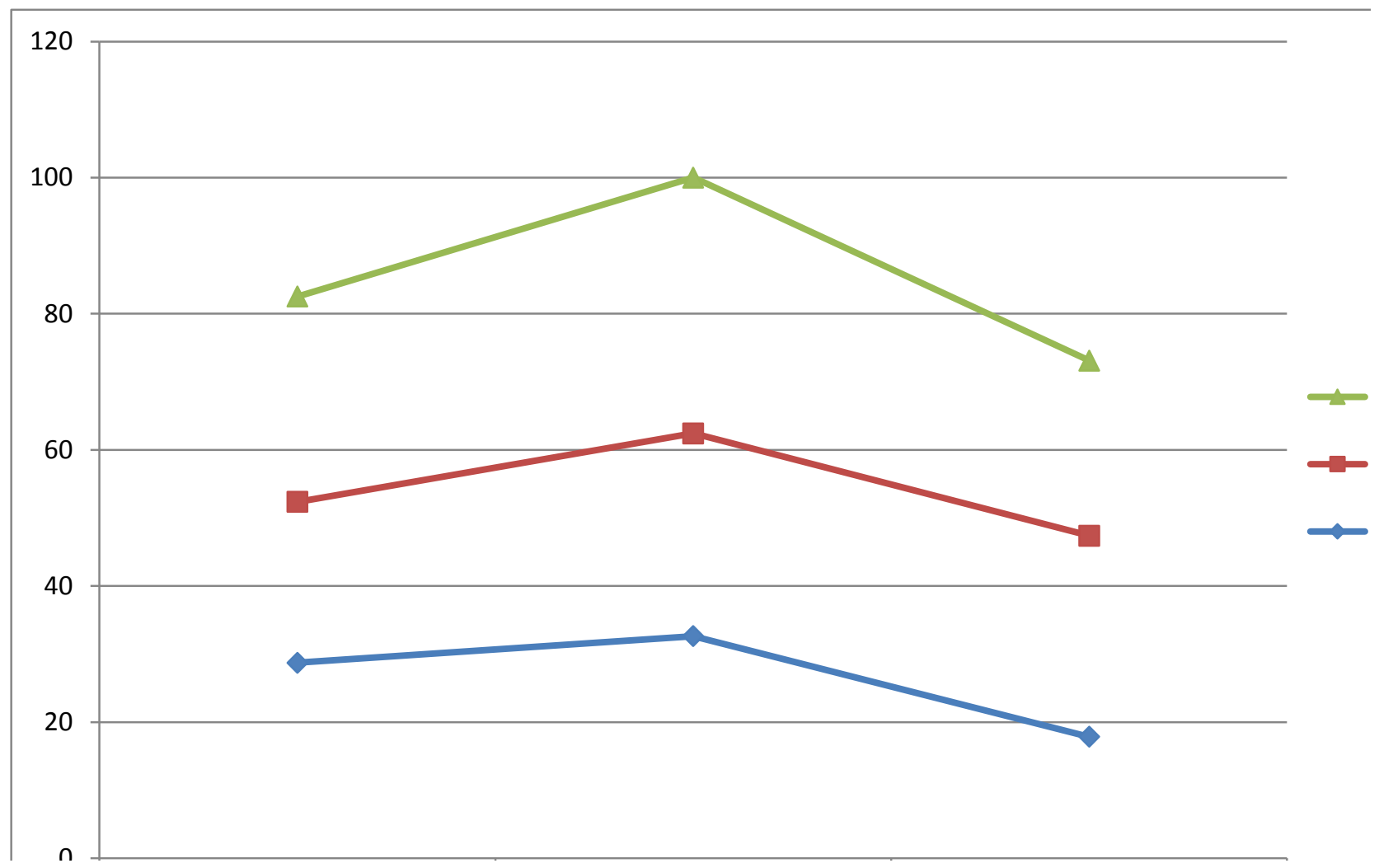

Figure 1: Time dependent changes in plasma SCUBE1 levels in the study groups.

\section{DISCUSSION}

This prospective clinical study investigated the value of SCUBE1, described in the literature as a potential biomarker in atherosclerosis and ischemia-related pathologies, in etiologies in patients presenting to the emergency department with angina pectoris. We determined no difference between SCUBE1 levels in our independent patient groups.

Our first study finding concerned the levels of distribution of ischemic chest pain. NSTEMI was identified as the most common cause in this study. This finding is not in agreement with levels cited in previous studies. Approximately $15 \%$ of patients presenting to the emergency department with chest pain are diagnosed with AMI, while $25-30 \%$ are diagnosed with UAP (9). The principal factor behind our finding may be that the center in which the study was performed is a tertiary health institution where 24 -h primary coronary procedures are applied and to which MI patients are referred from external centers.

Platelet aggregation is known to lead to ACS and other ischemic events. Studies have identified SCUBE1 in the systemic circulation through being released from human platelets and have thus shown that they may represent a potential biomarker in acute thrombotic events $(6,7,10)$. In one clinical study, Dai et al. investigated plasma SCUBE1 levels in acute coronary syndrome and acute ischemic stroke. Healthy individuals were enrolled as the control group in that study, together with patients with chronic coronary artery disease. Significant elevation was determined in ACS and AIS predominantly involving thrombotic reaction, but no significant elevation was observed in subjects with CAD (11). The absence of a significant increase in plasma SCUBE1 in CAD may be due to smooth muscle cell proliferation in stable atherosclerotic plaques and the extracellular matrix 
being covered by a thick fibrous capsule, for which reason less inflammation and massive platelet reaction occur when plaque rupture occurs $(12,13)$. Our study investigated the value of plasma SCUBE-1 levels in the diagnosis of etiologies of angina pectoris, and patients were first classified into SAP, UAP, STEMI and NSTEMI subgroups on the basis of their clinical, ECG and laboratory findings. However, no significant variation was determined in SCUBE1 levels investigated in blood specimens taken from patients in all groups, particularly at time of presentation and at 6 and $12 \mathrm{~h}$, compared to the healthy control group. Such an increase may not have been observed due particularly to the presence of $\mathrm{CAD}$ and stable atheromatous plaques in the SAP development mechanism, but the acute thrombotic reaction occurring in UAP, STEMI and NSTEMI not causing a significant increase in plasma SCUBE1 levels is an unexpected finding. This may be due to absence of standard timing of blood specimens collected at time of presentation, because times of onset of symptoms differed from one another. Studies have shown that SCUBE1 levels in serum reach detectable levels $6 \mathrm{~h}$ after thrombotic reactions at the earliest, that they peak at $36 \mathrm{~h}$ and remain measurable for 3-4 days (11). In our study, however, levels tended to decrease after $6 \mathrm{~h}$.

There are a number of limitations to this study. First, our patient presentations were not made after standard time intervals had elapsed. Plasma SCUBE1 levels may therefore have been affected depending on time of presentation. Second, our low patient numbers may have impacted on statistical significance. Finally, only plasma SCUBE1 levels were measured from these patients, and no comparison was performed with other potential biomarkers.

In conclusion, our study is one of the first studies to investigate the value of plasma SCUBE1 in the diagnosis of etiologies of angina pectoris, and the findings obtained indicate that plasma SCUBE1 levels are of no diagnostic value in terms of causes of ACS in particular and other ischemic chest pains.

\section{REFERENCES}

1. Pope JH, Ruthazer R, Beshansky JR, Griffith JL, Selker HP. Clinical Features of Emergency Department Patients Presenting with Symptoms Suggestive of Acute Cardiac Ischemia: A Multicenter Study. J Thromb Thrombolysis. 1998;6(1):63.

2. Ibáñez B, Heusch G, Ovize M, Van de Werf F. Evolving therapies for myocardial ischemia/reperfusion injury. J Am Coll Cardiol. 2015;65(14):1454-71.

3. Vedanthan R, Seligman B, Fuster V. Global perspective on acute coronary syndrome: a burden on the young and poor. Circ Res. 2014;114(12):1959-75.

4. Tu CF, Yan YT, Wu SY, Djoko B, Tsai MT, Cheng $\mathrm{CJ}$, et al. Domain and functional analysis of a novel platelet-endothelial cell surface protein, SCUBE1. J Biol Chem. 2008;283:12478-88.

5. Peacock WF. Will SCUBE1 solve the ischemia marker deficit? J Am Coll Cardiol. 2008;51:2181-3.

6. Turkmen S, Sahin A, Gunaydin M, Sahin S, Mentese A, Turedi S, et al. The value of signal peptide-CUB-EGF domain-containing protein-1 (SCUBE1) in the diagnosis of pulmonary embolism: a preliminary study. Acad Emerg Med. 2015;22(8):922-6.

7. Turedi S, Tatli O, Alver A, Karaguzel E, Karaca Y, Turkmen S, et al. The Diagnostic Value of Plasma SCUBE1, a Novel Biomarker of Platelet Activation, in Testicular Torsion: A Randomized, Controlled, Experimental Study. Urology. 2015;86(3):516-20. 
8. Hamm CW, Bassand JP, Agewall S, Bax J, Boersma E, Bueno H, et al. ESC Guidelines for the management of acute coronary syndromes in patients presenting without persistent ST-segment elevation: Task Force for the Management of Acute Coronary Syndromes in Patients Presenting without Persistent ST-Segment Elevation of the European Society of Cardiology (ESC). Eur Heart J. 2011;32(23):2999-3054.

9. Braunwald E, Antman EM, Beasley JW. ACC/AHA guidelines for themanagement of patients with unstable angina and non-ST-segment elevation myocardial infarction: executive summary and recommendations: a report of the American College of Cardiology/American Heart Association Task Force on Practice Guidelines Committee on Management of Patients with Unstable Angina. Circulation. 2000;102:1193-209.

10. Yeniocak S, Saraç F, Karadana GA, Olgaç V, Kalkan A, Düz ME, et al. Diagnostic Value of Signal Peptide, CUB (Complement C1r/C1s, Uegf, and Bmp1), EGF (Epidermal Growth Factor)-Like Domain-Containing Protein 1 (SCUBE1) and Chemerin in Experimental Testicular Torsion. Eurasian J Emerg Med. 2017;16:48-53.
11. Dai DF, Thajeb P, Tu CF, Chiang FT, Chen $\mathrm{CH}$, Yang RB, et al. Diagnostic Value of Signal Peptide, CUB (Complement C1r/C1s, Uegf, and Bmp1), EGF (Epidermal Growth Factor)-Like DomainContaining Protein 1 (SCUBE1) and Chemerin in Experimental Testicular Torsion. Eurasian J Emerg Med. 2017;16:48-53.

12. Sarma J, Laan CA, Alam S, Jha A, Fox KA, Dransfield I. Increased platelet binding to circulating monocytes in acute coronary syndromes. Circulation. 2002;105:2166-71

13. Furman MI, Benoit SE, Barnard MR, Valeri CR, Borbone ML, Becker RC et al. Increased platelet reactivity and circulating monocyte-platelet aggregates in patients with stable coronary artery disease. J Am Coll Cardiol. 1998;31:352-8. 